Western North American Naturalist 68(3), (C) 2008, pp. 265-277

\title{
EFFECTS OF A SPRING PRESCRIBED BURN ON THE SOIL SEED BANK IN SAGEBRUSH STEPPE EXHIBITING PINYON-JUNIPER EXPANSION
}

\author{
Elizabeth A. Allen ${ }^{1,2}$, Jeanne C. Chambers ${ }^{3}$, and Robert S. Nowak ${ }^{2,4}$
}

\begin{abstract}
Pinyon-juniper (Pinus monophylla-Juniperus osteosperma) woodlands are expanding into shrubsteppe ecosystems in western portions of the Great Basin. Often, highly competitive trees displace the understory, and prescribed fire is increasingly used as a restoration tool. To inform management decisions about post-fire recovery, we examined immediate and long-term (i.e., 2 growing seasons) responses of the germinable seed bank to a spring prescribed fire. One week before and 1 week after a May 2002 prescribed burn, soil samples were taken under P. monophylla trees, under Artemisia tridentata ssp. vaseyana shrubs, and from interspace microsites. Two growing seasons after the prescribed burn, soil samples were taken from the same microsites and from similar microsites in an adjacent unburned area. Prior to the burn, the germinable seed bank under shrubs contained the highest seed density and the highest species richness followed by interspace and tree microsites. Shrub litter was consumed by the burn, causing complete loss of the seed bank from that microsite and depleting the A. tridentata seed bank. Interestingly, the density of germinable seeds in soil under P. monophylla trees increased immediately following the burn; $70 \%$ of that increase originated from the annual forb Descurainia pinnata. Two growing seasons following the prescribed burn, no overall differences in germinable seed density between burned and unburned plots were observed, but seed bank species composition differed, with seed banks in the prescribed burn having a greater abundance of Eriogonum elatum, E. microthecum, and Gayophytum diffusum compared to unburned plots, which had a greater abundance of A. tridentata, Lappula occidentalis, and Descurainia pinnata. Our results indicate that rapid restoration to prefire vegetation cannot rely upon the soil seed bank. To ensure rapid recovery, land managers should select sites for prescribed burns that have fire-tolerant perennial vegetation.
\end{abstract}

Key words: Pinus monophylla, Juniperus osteosperma, Artemisia tridentata, seed density, seed richness, microsite, soil depth, ecosystem restoration.

Nomenclature: USDA, NRCS. 2006. The PLANTS Database [cited 13 November 2006]. National Plant Data Center, Baton Rouge, LA 70874-4490. Available from: http://plants.usda.gov

Pinyon-juniper woodlands of the western Great Basin have expanded their range and increased in density since the introduction of intensive land-use practices after 1860 (Miller and Wigand 1994). These woodlands, which are dominated by Pinus monophylla Torr. \& Frém. (singleleaf pinyon) and Juniperus osteosperma (Torr.) Little (Utah juniper), are becoming established in Artemisia tridentata Nutt. shrubsteppe ecosystems, Populus tremuloides Michx. stands, and riparian communities. This woodland expansion in the Great Basin has been attributed to cumulative effects of climate change, overgrazing by livestock, and fire exclusion (Miller and Wigand 1994, Miller and Rose 1999). As tree density and biomass increase in encroached shrubsteppe, understory vegetation is often reduced in cover and species are lost (Naillon et al. 1999, Miller and Tausch 2001). Closing of the woodland canopy also increases fuel loads and the risk of high-severity fires that decimate large tracts of mountain terrain and increase susceptibility to erosion and to invasion by exotic species such as Bromus tectorum L. (Tausch 1999, Reiner 2004). To reduce the risk of catastrophic fires and restore shrubsteppe ecosystems, land managers use prescribed fire to prevent tree dominance (Miller and Tausch 2001). Concerns about the high costs of reseeding prescribed burn sites and about the uncertain effectiveness of reseeding efforts have increased interest in the natural capacity for post-fire plant recovery.

Community response after fire is controlled by (1) survival and subsequent regrowth of existing vegetation, (2) establishment of new

\footnotetext{
${ }^{1}$ Conservation Science Department, Chicago Botanic Garden, 1000 Lake Cook Rd., Glencoe, IL 60022.

${ }^{2}$ Department of Natural Resources and Environmental Science, Mailstop 370, University of Nevada, Reno, Reno, NV 89557

${ }^{3}$ U.S. Forest Service, Rocky Mountain Research Station, 920 Valley Road, Reno, NV 89512.
}

${ }^{4}$ Corresponding author. E-mail: nowak@cabnr.unr.edu 
plants from existing reserves in either seed or vegetative banks, and (3) dispersal of seed from adjacent areas into the burned area. In the western Great Basin, the 2 dominant tree species (P. monophylla and J. osteosperma) and the dominant shrub (A. tridentata) often are killed by fire. Consequently, early post-fire vegetation can be dominated by annuals and species that were sparse in the prefire vegetation (Everett and Ward 1984). In these types of environments, knowledge of the density and composition of the soil seed bank after fire is important for predicting post-fire vegetation composition.

Seed bank response to fire depends on how individual species respond to conditions created both during and after a fire. Increased inorganic nitrogen, smoke, and leachate from charred wood stimulate germination of some species (Baskin and Baskin 1998). Heat transferred to the soil also breaks physical dormancy in some species if soil temperatures are between $60^{\circ}$ and $100^{\circ} \mathrm{C}$, although temperatures sustained for more than a few minutes above $100^{\circ} \mathrm{C}$ kill most seeds (Baskin and Baskin 1998). Also, loss of aboveground vegetation promotes germination by increasing light levels and soil temperatures (McPherson and Muller 1969, Christensen and Muller 1975). In the Great Basin, enhanced germination from fire cues has been demonstrated in a few species, such as Achnatherum thurberianum (Piper) Barkworth, Hesperostipa comata (Trin. \& Rupr.) Barkworth, and Nicotiana attenuata Torr. ex S. Wats. (Baldwin and Morse 1994, Blank and Young 1998, Wehking 2002).

Seed banks vary spatially, with higher seed densities under woody vegetation than on bare ground in open spaces between plants (Kemp 1989). Although the mechanisms responsible for this effect are not completely elucidated, important factors include higher seed entrapment under woody vegetation for abiotically dispersed seeds (Johnson and Fryer 1992) and conditions under woody vegetation conducive to seed persistence, such as low likelihood for germination, granivory, and fungal attack (Chambers 2001). Seed density also varies vertically, with seed density generally decreasing with depth (Guo et al. 1998). Plant litter acts as a physical barrier trapping seeds (Chambers 2001), and seed banks in surface litter may have a different species composition than seed banks in mineral soil (Strickler and Edgerton 1976, Halpern et al. 1999).

Seed bank data for shrubsteppe ecosystems and pinyon-juniper woodlands in western North America are limited. Annual species comprise $89 \%$ of the seed bank across successional stages between dominance by $A$. tridentata and dominance by P. monophylla and J. osteosperma, and few perennial species are present in the seed bank (Koniak and Everett 1982). Seed density also differs by microsite, and a few species display high affinity to a particular microsite. In addition, fire in shrubsteppe communities reduces both seed density in shrub microsites and species similarity in the seed bank between burned and unburned areas (Hassan and West 1986, Wehking 2002). In different $P$. monophylla-J. osteosperma woodland sites, initial species composition after prescribed burns is highly variable due to varying recruitment from the seed bank versus regrowth from fire-tolerant species (Everett and Ward 1984).

This study addressed 4 questions related to immediate and long-term (i.e., 2 growing seasons) effects of a spring prescribed burn on the seed bank of expanding $P$. monophylla-J. osteosperma woodlands. A spring burn was used because the low fire intensity at this time of year results in a more easily controlled burn and because interagency fire personnel are more readily available in the spring to conduct prescribed burns. Questions addressed in this study were the following: (1) Does spring prescribed fire have an immediate effect on seed density, species richness, and species composition of the seed bank? (2) Do immediate effects of prescribed fire vary by microsite or soil depth? (3) After 2 growing seasons, do seed density, species richness, and species composition differ between burned and unburned sites? And (4) after 2 growing seasons, do effects of prescribed fire vary by microsite?

\section{Methods}

\section{Study Site}

The study site $\left(39^{\circ} 10^{\prime} \mathrm{N}, 117^{\circ} 25^{\prime} \mathrm{W}\right)$ was Underdown Canyon in the Shoshone Mountains of central Nevada. The site has a typical Great Basin climate of hot dry summers and cool wet winters. Mean daily temperature for Austin, Nevada, which is about $50 \mathrm{~km}$ north and at a slightly lower elevation (2066 m) than 
the study areas, is $21.2^{\circ} \mathrm{C}$ in July and $-1.4^{\circ} \mathrm{C}$ in January (Western Regional Climate Center 2005). Average annual precipitation for Austin is $318 \mathrm{~mm}$ and occurs mostly in winter and spring. Soils are coarse loamy mixed frigid Typic Haploxerolls with extremely coarse grains and weak to moderate structure (Rau et al. 2006, Rau et al. 2007).

Two adjacent study areas with similar slopes $(7 \%$ and $5 \%)$ were located on north-facing alluvial fans at $2195 \mathrm{~m}$ and $2252 \mathrm{~m}$ in Underdown Canyon. Three replicate plots, each 15 $\times 25 \mathrm{~m}$, were located in each study area. Vegetation of the study site was characterized by Artemisia tridentata ssp. vaseyana and Pinus monophylla with lesser cover of Juniperus osteosperma (MontBlanc et al. 2007). Total tree cover was about $39 \%$. Herbaceous species included the grasses Poa secunda ssp. secunda J. Presl, Elymus elymoides Swezey, Hesperostipa comata, Festuca idahoensis Elmer, and Pseudoroegneria spicata (Pursh) A. Löve. Abundant forbs included Eriogonum umbellatum Torr., Eriogonum ovalifolium Nutt., Eriogonum elatum Dougl. ex Benth., Eriogonum heracleoides Nutt., Crepis acuminata Nutt., Phlox longifolia Nutt., Agoseris glauca (Pursh) Raf., Lupinus argenteus Pursh, and Penstemon spp. The invasive annual grass Bromus tectorum is a small component of the vegetation.

On 11-12 May 2002, the U.S. Forest Service conducted a prescribed burn on the study area at $2252 \mathrm{~m}$ elevation. The fire was a cool, spring burn that was patchy in nature. Maximum soil temperatures during the burn were recorded using metal strips with a series of heat sensitive paints that ranged from $39^{\circ}$ to $788^{\circ} \mathrm{C}$ in $28^{\circ} \mathrm{C}$ increments. Strips were placed parallel to the soil surface at $0-, 0.02-$, and 0.05-m soil depths in all microsites (see Korfmacher et al. 2002). Maximum surface temperature was $304^{\circ} \mathrm{C}$ under trees, $369^{\circ} \mathrm{C}$ under shrubs, and $206^{\circ} \mathrm{C}$ in the interspaces between perennial plants (Rau et al. 2007). However, many temperature strips recorded cooler temperatures. For example, about $20 \%$ of the surface temperature strips did not exceed $107^{\circ} \mathrm{C}$, and $<20 \%$ of the temperature sensors at $0.02 \mathrm{~m}$ depth registered a temperature $\geq 86^{\circ} \mathrm{C}$.

\section{Seed Bank Sampling}

We sampled the seed bank 1 week prior to and 1 week following the prescribed burn in
May 2002 to examine immediate effects of the fire on the seed bank. To examine long-term effects of the prescribed burn, burned sites and adjacent unburned sites were sampled in late October 2003, which was 2 growing seasons after the prescribed burn and after the majority of plants had released their seeds. We switched to fall sampling of the seed bank for the long-term portion of our study to allow comparisons with other seed bank studies, wherein samples were typically collected after seed dispersal in order to maximize seed density and diversity. Because the potential for seed entrapment and for fire effects on the seed bank differ spatially, 3 microsites were sampled: under tree, under shrub, and in the interspace between perennial plants. Pinus monophylla and Artemisia tridentata ssp. vaseyana were the most abundant tree and shrub species, respectively; therefore all tree and shrub microsite sampling points were randomly selected from the available pool of these species. Tree microsites had at least 1 branch with a length of $\geq 2 \mathrm{~m}$. Shrub microsites had a diameter of at least $0.5 \mathrm{~m}$. The interspaces were chosen based on the largest amount of undisturbed ground adjacent to a sampled shrub with a minimum diameter of $0.3 \mathrm{~m}$. The dimensions of the microsites in the burned site were measured prior to the fire. We followed a sampling approach of collecting numerous but small seed bank samples, as advised by seed bank methodology papers (Bigwood and Inouye 1988, Gross 1990). Thus, 10 sampling points were located within each microsite for each of 3 replicate plots within the burned and unburned areas.

We also sampled the seed bank at various soil layers, because (1) litter layers tend to trap seeds, (2) viable seed abundance decreases with depth below the surface (Chambers and MacMahon 1994), and (3) heat from fires decreases with depth (Steuter and McPherson 1995). To examine immediate effects of the prescribed burn, seed bank samples were collected from up to 3 soil layers. Sample depths for preburn samples included litter, $0-0.01 \mathrm{~m}$, and $0.01-0.05 \mathrm{~m}$ for shrub and tree microsites, and $0-0.01 \mathrm{~m}$ and $0.01-0.05 \mathrm{~m}$ for interspace microsites. Because the shrub litter layer was largely consumed in the fire, post-burn samples of both shrub and interspace microsites included only $0-0.01 \mathrm{~m}$ and $0.01-0.05 \mathrm{~m}$ depths. The $P$. monophylla litter, although reduced, 
remained and was sampled. For seed bank samples that were collected 2 growing seasons after the prescribed burn, we were interested in the total seed bank. Thus, we did not divide the soil into depth layers but rather collected a single $0-0.05-\mathrm{m}$ sample, except for the soil at tree microsites, where we also sampled the litter layer.

The sampling location for preburn samples was the southeast quadrant of the canopy for both shrub and tree microsites and the center of the interspace for the interspace microsite. Because the canopy of the trees encompassed a relatively large area, seed bank samples were taken $0.5 \mathrm{~m}$ in from the edge of the canopy. Each sample point was then refilled with soil from outside the plot. To avoid resampling the exact same spot, we marked each sample location, and subsequent samples were taken 0.2 $\mathrm{m}$ away from previous sample locations. Seed bank samples were obtained by hammering a hollow, square metal template $(0.1 \times 0.1 \times$ $0.05 \mathrm{~m}$ ) into the ground, retrieving the soil, and placing the soil in a labeled freezer bag.

\section{Seed Bank Determination}

Seed bank samples that were collected immediately before and after the prescribed fire were assumed to be already vernalized because these samples were collected in spring. However, to prevent seed germination before seed bank determination could begin, these spring samples were placed into cold storage at $3^{\circ}-4^{\circ} \mathrm{C}$ for $1.5-2.5$ weeks after sample collection. Seed bank determination of pre- and post-burn samples began in June. In contrast, seed bank samples collected in fall to examine effects after 2 growing seasons were cold, wet stratified for at least 90 days at $3^{\circ}-4^{\circ} \mathrm{C}$ before seed bank determination began. Seed bank determination of these latter samples began in February.

The seed bank was determined by the germination method (Gross 1990). We chose the germination method because we were interested in the immediate impact of fire on the seed bank, and thus we needed to quantify germinable seeds. Samples were spread over sterilized sand in square germination flats $(0.25 \times 0.25 \times 0.05 \mathrm{~m})$ in a greenhouse. Sample thickness averaged $0.008 \mathrm{~m}$, which allows for optimal germination (Freas and Kemp 1983, Ter Heerdt et al. 1996). Flats were well watered to induce seed germination and given a diluted dose of 20-20-20 NPK fertilizer about 4 weeks into the germination trial. Nutrient addition increases seedling growth, and nitrogen also induces some seeds to germinate (Karssen and Hilhorst 1992). Finally, we simulated natural environmental conditions by allowing a diurnal temperature fluctuation between $13^{\circ}$ and $30^{\circ} \mathrm{C}$ in the greenhouse, similar to temperature fluctuations in the Great Basin. Flats were exposed to natural light-dark cycles.

As seeds germinated, individual seedlings were counted and identified to species if possible. Unknown seedlings were transferred to a pot containing a mixture of sand and potting soil and identified to species upon flowering. Any individuals of the same unknown species remaining in the flats were recorded and plucked to reduce the risk of competitive effects on other seedlings. Because different subspecies of the shrub Artemisia tridentata are identified by the inflorescence, we report these seedlings simply as A. tridentata, even though ssp. vaseyana was the dominant subspecies present at the study site.

Emergence of new seedlings usually abated about 2 months after seed bank samples were first watered. To simulate typical spring conditions, flats were allowed to dry. After 2 weeks of drying, we again watered flats and counted new seedlings. The total time for 2 wetting and drying cycles was between 3 and 4 months. Total number of seedlings that emerged during both wetting cycles became our measure of germinable seeds in the seed bank.

\section{Statistical Analyses}

We were interested in 3 major characteristics of the seed bank: seed density, species richness, and community composition. Although we actually measured seedlings, the word "seed" is used for brevity. Seed density was the number of emerged seedlings in a seed bank sample divided by the $0.01-\mathrm{m}^{2}$ cross-sectional area of the metal sampling template. Species richness was the total number of species in a sample and also was expressed on a unit-area basis. We use the term "seed bank response" collectively for both seed density and species richness.

To determine immediate effects of the prescribed burn on the seed bank, we first conducted analyses of preburn data to evaluate whether any differences existed among microsites and soil layers prior to the fire. Total seed 

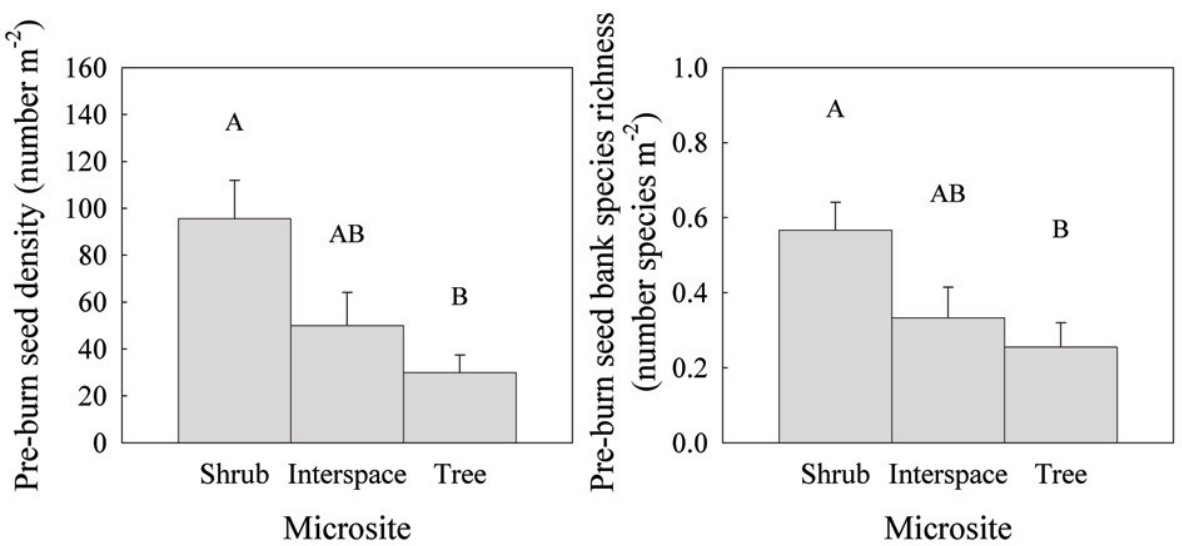

Fig. 1. Mean seed density (left panel) and species richness (right panel) of germinable seeds in the seed bank 1 week prior to a spring prescribed burn for shrub, tree, and interspace microsites $(n=30$ for each microsite). Seed bank was sampled to a depth of $0.05 \mathrm{~m}$ and where applicable, a litter layer was included. Letters represent statistical differences among microsites $(P \leq 0.05)$. Bars represent 1 standard error.

TABLE 1. Type III ANOVA table comparing microsite and depth for preburn germinable seed density and species richness. Data were taken 1 week before a prescribed fire in early May 2002. Tree and shrub microsites contained a litter layer and $0.0-0.01-\mathrm{m}$ and $0.01-0.05-\mathrm{m}$ soil layers; interspace had $0.0-0.01-\mathrm{m}$ and $0.01-0.05-\mathrm{m}$ soil layers only.

\begin{tabular}{lccccccccc}
\hline & \multicolumn{4}{c}{ Preburn seed density } & & \multicolumn{3}{c}{ Preburn seed richness } \\
\cline { 2 - 3 } Effect & Num. df & Den. df & $F$ & $P>F$ & & Num. df & Den. df & $F$ & $P>F$ \\
\hline Microsite & 2 & 88 & 5.40 & 0.006 & & 2 & 87 & 4.56 & 0.013 \\
Depth (microsite) & 5 & 147 & 0.91 & 0.479 & & 5 & 147 & 0.48 & 0.790 \\
\hline
\end{tabular}

density was analyzed with a mixed-model ANOVA that had microsite as a main factor and soil layer as a nested repeated measure (Proc Mixed in SAS Version 9). Seed density was transformed to meet ANOVA assumptions of equal variances and normality. Although we also analyzed post-burn data in a similar manner, the experimental design used paired sampling, and thus the fire effect was best inferred from the difference in seed density between the paired preburn and post-burn samples. Effects of spatial microsite and soil depth on this difference in seed density were examined with the same mixed-model ANOVA that was used for preburn sample analyses. All mean comparisons were calculated using Tukeyadjusted least square means. In addition, a Wilcoxon's signed-rank test was used to determine if the median difference in seed density deviated enough from 0 to suggest a treatment (prescribed burn) effect. We used similar ANOVA's to examine changes in species richness. However, analyses of number of species alone can be misleading. For example, both preburn and post-burn samples could contain
2 species within the same matched pair of soil samples, but these species could be different from each other. Thus, we also used community analysis techniques for species composition data (see next paragraph). Seed density and species richness from October 2003 samples (i.e., 2 growing seasons after the prescribed burn) were analyzed using a 2-factor mixed-model ANOVA with presence/absence of prescribed fire as 1 factor and 3 microsites as the other factor. For all statistical analyses, results were statistically significant if $P \leq 0.05$.

To examine community-level responses to treatment (fire) across variations in microsite and soil depth, both immediate and long-term fire effect data were evaluated using multiresponse permutation procedures (MRPP) and nonmetric indicator species analysis. MRPP is a nonparametric method that tests for group community-level differences (Biondini et al. 1985). The procedure yields a test statistic $T$, a value for the effect size $A$, and a $P$-value (McCune and Grace 2002). By using MRPP, community-level differences in seed banks between fire treatments and among microsites 
TABLE 2. Type III ANOVA table for differences between pre- and post-burn germinable seed bank responses taken at the same spatial location. Data were taken 1 week before and 1 week after a prescribed fire, respectively, in early May 2002. Tree and shrub microsites contained a litter layer and $0.0-0.01-\mathrm{m}$ and $0.01-0.05-\mathrm{m}$ soil layers; interspace had $0.0-0.01-\mathrm{m}$ and $0.01-0.05-\mathrm{m}$ soil layers only.

\begin{tabular}{lccccccccc}
\hline & \multicolumn{4}{c}{ Pre- vs. post-burn seed density } & & \multicolumn{3}{c}{ Pre- vs. post-burn seed richness } \\
\cline { 2 - 4 } Effect & Num. df & Den. df & $F$ & $P>F$ & & Num. df & Den. df & $F$ & $P>F$ \\
\hline Microsite & 2 & 94 & 2.88 & 0.061 & & 2 & 89 & 3.52 & 0.034 \\
Depth (microsite) & 5 & 150 & 3.66 & 0.004 & & 5 & 146 & 2.21 & 0.056 \\
\hline
\end{tabular}

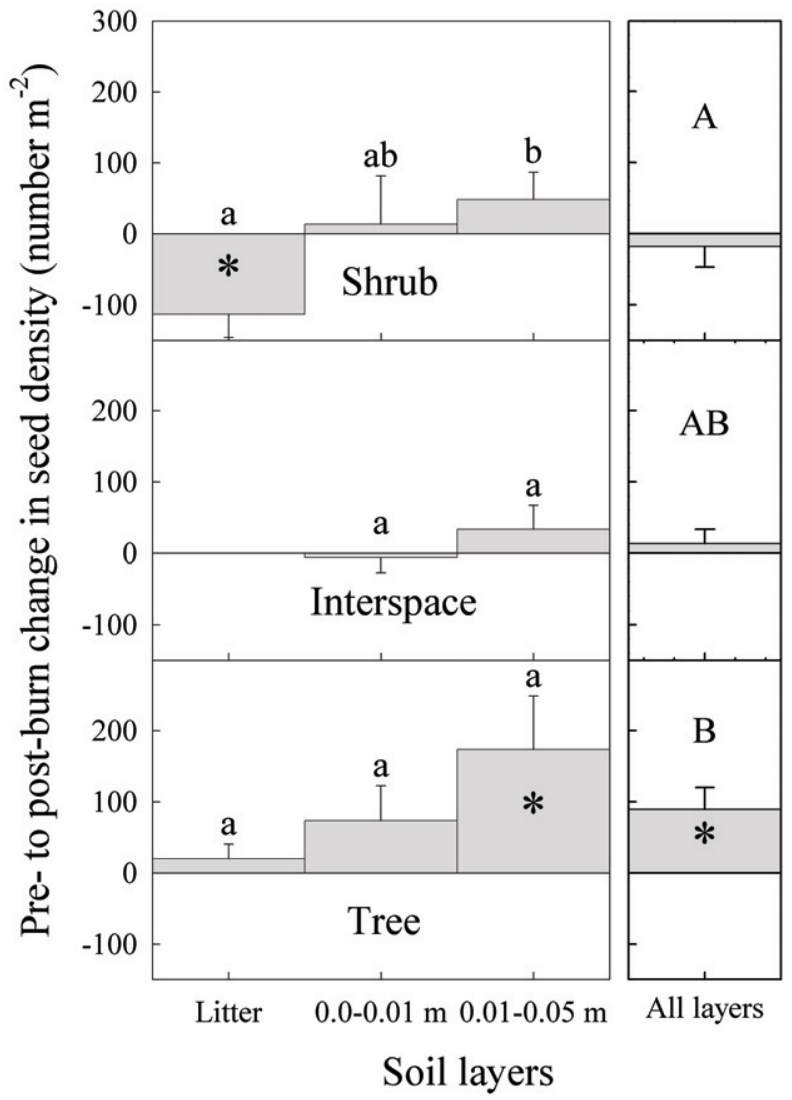

Fig. 2. Mean change in seed density for the germinable seed bank. Response is post-burn minus preburn seed density. Left panels are differences in seed density by microsite and soil layer $(n=30)$. Right panels are differences by microsite summed over all soil layers: shrub $(n=90)$, interspace $(n=60)$, and tree $(n=90)$. Lowercase letters within the left panels indicate differences among soil layers within that microsite. Uppercase letters among the right panels indicate overall differences among microsites from top to bottom. Asterisks indicate that the difference between preand post-burn seed density is significantly different from 0 using Wilcoxon's signed-rank test. Only statistical differences with $P \leq 0.05$ are shown. Bars represent 1 standard error.

could be detected, as well as the significance of the treatment $\times$ microsite interaction. All significant MRPP analyses were followed by indicator species analysis to determine if any species had a propensity towards a treatment. PC-ORD (version 4.25, Gleneden Beach, OR) was used for all community-level analyses.

\section{REsULTS}

Immediate Effects of Prescribed Burn on Germinable Seed Banks

Prior to the prescribed burn, germinable seed banks differed among microsites (Table 1). 
The preburn shrub microsite had higher seed density and species richness than the tree microsite, whereas the interspace microsite was intermediate between the shrub and tree microsites (Fig. 1). Differences among the litter layer and individual soil depth layers were not significant within a microsite for both seed bank characteristics (Table 1). Because the size of a particular microsite may affect both seed entrapment and fire temperature, we determined if seed density or species richness of the seed bank were related to litter depth or microsite size. Shrub litter depth averaged $0.011 \mathrm{~m}$ (range $0.0-0.03 \mathrm{~m}$ ) and tree litter depth averaged $0.048 \mathrm{~m}$ (range $0.02-0.13 \mathrm{~m}$ ). Average shrub microsite diameter was $0.49 \mathrm{~m}$ (range 0.31-0.66 m), tree microsite diameter was 4.37 $\mathrm{m}$ (range 2.9-6.1 m), and interspace microsite diameter was $1.56 \mathrm{~m}$ (range 0.73-2.4 m). Regression analyses and nonparametric tests of association showed no relationship between microsite dimensions and preburn seed density or species richness (data not shown).

The shrub litter layer was entirely consumed during the burn, and tree litter depth was reduced to $0.032 \mathrm{~m}(\sim 75 \%$ of preburn depth). The majority of shrubs were burned to the ground, whereas tree needles were mostly consumed in the fire, while woody tree skeletons remained. As with preburn data sets, seed density and species richness in the seed bank after the prescribed burn were not associated with either litter depth or microsite diameter.

The most salient changes in seed density immediately after the prescribed fire were a complete loss of germinable seeds in the shrub litter layer and an apparent increase in seed density in the tree $0.01-0.05-\mathrm{m}$ soil layer (Table 2, Fig. 2). ANOVAs determined the relative ordering and significant differences among microsite and depth factors. We also used Wilcoxon's signed-rank test to determine whether differences between pairs of pre- and postburn samples were statistically different from 0 , which would imply prescribed burn effects. Over all microsites and soil layers, seed densities for preburn $\left(60 \pm 7.8\right.$ seeds $\left.\cdot \mathrm{m}^{-2}\right)$ and post-burn $\left(90 \pm 15.9\right.$ seeds $\left.\cdot \mathrm{m}^{-2}\right)$ samples were not significantly different from each other (Table 2), and the difference between pre- and post-burn seed density was not significantly different from 0 . However, some significant differences occurred within specific microsites.
Seed density in the shrub litter layer declined by over 100 seeds $\cdot \mathrm{m}^{-2}$ after the prescribed burn, and this decrease was significantly greater than that for the shrub $0.01-0.05-\mathrm{m}$ soil layer (Fig. 2, top left panel). This decrease in seed density for the shrub litter layer was significantly different from 0 and was due to the fire completely burning the litter layer. However, changes in seed density after prescribed fire for the shrub microsite were not significantly different from 0 for the 2 other depths $(0.0-0.01 \mathrm{~m}$ and $0.01-0.05 \mathrm{~m})$ as well as over all depths (Fig. 2, top right panel). Within interspace and tree microsites, changes in seed density after the fire were not significantly different among litter and soil layers (Fig. 2, left panels), and except for the 0.01$0.05-\mathrm{m}$ soil layer under trees, changes in seed density were not significantly different from 0 (Fig. 2, right panels). For the 0.01-0.05-m soil layer under trees, seed density significantly increased by almost 175 seeds $\cdot \mathrm{m}^{-2}$. Consequently, seed density over all tree soil layers significantly increased after the fire (Fig. 2, lower right panel). The tree microsite had a significantly greater change in seed density after the prescribed burn than the shrub microsite had.

Over all microsites and soil layers, the germinable seed bank for preburn (18 species) and post-burn (24 species) samples shared 12 species, indicating that a third of the preburn seed bank and half of the post-burn seed bank contained unique species. The unique species of the preburn seed bank comprised a small percentage $(10 \%)$ of the total seed bank, but the unique species in the post-burn seed bank contributed a much higher percentage (27\%) of the total seed bank.

Multiresponse permutation procedures (MRPP) revealed significant differences in overall species composition between pre- and post-burn seed banks (MRPP effect size $A=$ $0.06, P=0.002)$. The preburn seed bank was dominated by Artemisia tridentata and the post-burn seed bank by Descurainia pinnata (Walt.) Britt. (Table 3). Changes in the seed bank community following the prescribed burn were driven primarily by the loss of germinable seeds in the shrub litter layer and by the increase in germinable seeds in the tree 0.010.05-m soil layer. Shrub microsites, which had the highest preburn seed density of any microsite, contained $90 \%$ of the A. tridentata seeds 
TABLE 3. Percent composition by species for pre- and post-burn germinable seed banks. Species are listed in decreasing order of abundance in the preburn seed bank.

\begin{tabular}{llcc}
\hline Species & Life form & Preburn (\%) & Post-burn (\%) \\
\hline Artemisia tridentata & Shrub & 43.6 & 9.4 \\
Descurainia pinnata & Annual forb & 10.7 & 39.0 \\
Bromus tectorum & Annual grass & 9.3 & 2.3 \\
Unknown grass 2 & - & 6.4 & 6.6 \\
Poa secunda & Perennial bunchgrass & 5.7 & - \\
Lappula occidentalis ssp. occidentalis & Annual forb & 4.3 & 0.9 \\
Unknown lily & Perennial forb & 4.3 & 3.3 \\
Elymus elymoides & Perennial bunchgrass & 2.9 & 1.9 \\
Arabis holboellii & Perennial forb & 2.1 & 6.6 \\
Agrosteris spp. & - & 2.1 & - \\
Collinsia parviflora & Annual forb & 1.4 & 0.9 \\
Epilobium ciliatum & Perennial forb & 1.4 & 1.4 \\
Packera multilobata & Perennial forb & 1.4 & - \\
Lesquerella kingii & Perennial forb & 0.7 & - \\
Oenothera caespitosa & Perennial forb & 0.7 & 6.3 \\
Unknown grass 1 & - & - & 1.4 \\
Unknown herb 2 & - & - & 0.5 \\
Microsteris gracilis ssp. gracilis & Annual forb & - & 0.5 \\
Carex spp. & Perennial graminoid & - & 0.5 \\
Gayophytum diffusum & Annual forb & - & 0.5 \\
Gnaphalium palustre & Annual forb & - & - \\
Salix spp. & Shrub & & \\
Total for 6 unknown species, & & 2.9 & \\
with each species comprising $<2 \%$ of the seed bank & & \\
\hline
\end{tabular}

in litter and soil layers. This tendency of A. tridentata seeds to be located primarily under adult $A$. tridentata shrubs continued after the burn, even with a $78 \%$ reduction in A. tridentata's overall seed density. After the prescribed burn, the 0.01-0.05-m soil layer under trees had the greatest overall increase in seed density and species richness. The majority of this seed density increase was due to D. pinnata, which increased from 13 to 147 germinable seeds $\cdot \mathrm{m}^{-2}$.

\section{Germinable Seed Banks Two Growing Seasons after Prescribed Burn}

To assess long-term effects of the prescribed burn on germinable seed bank characteristics, we compared seed bank samples collected from the burned area in the fall, 2 growing seasons after the burn, with those collected at the same time from an adjacent unburned area. Overall seed density did not differ between burned (743 \pm 150 seeds $\left.\cdot \mathrm{m}^{-2}\right)$ and unburned plots $\left(635 \pm 217 \mathrm{seeds} \cdot \mathrm{m}^{-2}\right)$ or by microsite. Species richness also did not differ between burn treatments and among microsites. In descending order of percent composition, the germinable seed bank comprised annual forbs, perennial forbs, shrubs, perennial bunchgrasses, and annual grasses for a total of 43 species (Table 4). Of identifiable individuals, annual forbs contained the most species, but many of these species were rare in the seed bank.

Although seed density and species richness did not differ statistically between burned and unburned plots 2 growing seasons after the spring burn, species composition was different (MRPP A $=0.10, P \leq 0.001)$. Burned plots were dominated by Eriogonum elatum Dougl. ex Benth., E. microthecum Nutt., and Gayophytum diffusum Torr. \& Gray, which together accounted for $44 \%$ of the seed bank. All 3 species did occur in unburned plots, but collectively comprised $<3 \%$ of the unburned composition. In contrast, A. tridentata, Lappula occidentalis (S. Wats.) Greene ssp. occidentalis, and D. pinnata were abundant species on unburned plots. Indicator species analysis showed that 4 species had distinct affinities towards unburned plots and 9 species had affinities for burned plots (Table 5). Note that the test for $D$. pinnata did not indicate significance for indicator species analysis because of the highly variable seed density.

Differences in species composition between unburned and burned plots were also significant for all 3 microsites (MRPP results for 
TABle 4. Percent composition by species for the germinable seed bank in unburned and burned plots 2 growing seasons after a spring burn. Species are grouped into life forms. Only species that composed at least $1 \%$ of the seed bank for either unburned or burned plots are listed individually; all remaining species are grouped together for brevity.

\begin{tabular}{|c|c|c|}
\hline Species & $\begin{array}{l}\text { Unburned } \\
\qquad \%)\end{array}$ & $\begin{array}{c}\text { Burned } \\
(\%)\end{array}$ \\
\hline \multicolumn{3}{|l|}{ Annual forbs } \\
\hline Chenopodium leptophyllum & 2.9 & 2.1 \\
\hline Collinsia parviflora & 28.6 & 29.1 \\
\hline Descurainia pinnata & 19.4 & 2.6 \\
\hline Gayophytum diffusum & 1.3 & 11.4 \\
\hline Lappula occidentalis ssp. occidentalis & 11.7 & 0.4 \\
\hline Other species & 2.6 & 1.7 \\
\hline \multicolumn{3}{|l|}{ Annual grasses } \\
\hline Bromus tectorum & 1.3 & 3.9 \\
\hline \multicolumn{3}{|l|}{ Perennial forbs } \\
\hline Arabis ssp. & 1.4 & 2.0 \\
\hline Eriogonum elatum & 1.2 & 24.1 \\
\hline Eriogonum microthecum & 0.1 & 8.4 \\
\hline Lupinus caudatus ssp. caudatus & 0.0 & 1.5 \\
\hline Unknown herb 3 & 0.3 & 5.2 \\
\hline Unknown herb 4 & 4.2 & 0.0 \\
\hline Other species & 0.4 & 0.4 \\
\hline \multicolumn{3}{|l|}{ Perennial grasses } \\
\hline Achnatherum hymenoides & 4.6 & 0.2 \\
\hline Poa secunda & 1.7 & 0.0 \\
\hline Other species & 1.2 & 1.3 \\
\hline \multicolumn{3}{|l|}{ Shrubs } \\
\hline Artemisia tridentata & 14.7 & 1.5 \\
\hline Chrysothamnus viscidiflorus & 0.0 & 2.2 \\
\hline Species with unknown growth form & 2.4 & 2.0 \\
\hline
\end{tabular}

interspace microsite: $A=0.06, P=0.032$; shrub: $A=0.14, P=0.024$; and tree: $A=$ $0.12, P=0.042)$. Although not significant, mean seed density of interspace microsites was twice as great on burned plots (1250 \pm 397 seeds $\cdot$ $\left.\mathrm{m}^{-2}\right)$ as on unburned plots $(557 \pm 256$ seeds $\mathrm{m}^{-2}$ ); high sample variance likely precluded statistical significance for this interspace microsite. The majority of the increase in the interspace was due to an increase in 3 species: E. elatum, E. microthecum, and G. diffusum. For shrub microsites, D. pinnata and L. occidentalis ssp. occidentalis occurred mostly on unburned plots, and E. elatum occurred mostly on burned plots. Interestingly, indicator species analysis revealed that both Collinsia parviflora Lindl. and A. tridentata were associated with the shrub microsite, regardless of its burn status (Table 5). Tree microsites on burned plots contained more C. parviflora and E. elatum than did tree microsites on unburned plots, but tree microsites on unburned plots contained more D. pinnata, L. occidentalis ssp. occidentalis, and an unknown perennial forb than did tree microsites on burned plots. No species were consistently associated with tree microsites across both burned and unburned areas.

\section{Discussion}

\section{Preburn Germinable Seed Bank Characteristics}

Similar to other seed bank studies in semiarid shrubsteppe ecosystems, the preburn shrub microsite contained the highest density of seeds and the highest species richness (Koniak and Everett 1982, Parmenter and MacMahon 1983, Hassan and West 1986), followed by interspace and finally tree microsites. High seed density under shrubs is likely due to both a high probability of seed entrapment for abiotically-dispersed seeds, including those of the shrub, and a high occurrence of plants under the shrub canopy (Guo et al. 1998). Low seed density for tree microsites may seem unusual, because intuitively it seems that tree sites would trap a high number of abiotically dispersed seeds in tree litter. However, while extracting samples in the field, we observed extensive fungal hyphae intertwined with $P$. monophylla litter, which suggests that fungal pathogens may kill seeds while seeds are in the litter. Therefore, we suspect that tree litter may be beneficial for seed entrapment but not persistence. Also, because litter of $P$. monophylla is known to inhibit the emergence of many understory species (Everett et al. 1983), new seed input from plants under the tree may be low.

The apparent lack of a depth effect prior to the burn was somewhat unexpected given that seed bank studies often report declining seed density with depth (Kemp 1989, Guo et al. 1998). Seed density and species richness decreased with depth for both the shrub and tree microsites in our study, but lack of statistical difference may have been due to high sample variability, even though we followed the advice of seed bank methodology papers (Bigwood and Inouye 1988, Gross 1990) and collected numerous but small seed bank samples. However, the coarse texture of the soils (Rau et al. 2006) may have facilitated greater downward movement than is typical (see Chambers et al. 1991) and contributed to a smaller gradient in seed density with depth. 
TABLE 5. Indicator species analysis of germinable seeds 2 growing seasons after the prescribed burn. Species that indicate a specific burn treatment or microsite are listed; the associated $P$-value for the indicator value is shown in parentheses.

\begin{tabular}{|c|c|c|}
\hline Species & Overall burn type & Overall microsite \\
\hline Achnatherum hymenoides & Unburned (0.009) & - \\
\hline Achnatherum nevadense & - & Interspace $(0.045)$ \\
\hline Artemisia tridentata & Unburned (0.004) & Shrub $(0.042)$ \\
\hline Bromus tectorum & Burned $(0.081)$ & - \\
\hline Chrysothamnus viscidiflorus & Burned (0.095) & - \\
\hline Collinsia parviflora & - & Shrub $(0.007)$ \\
\hline Eriogonum elatum & Burned $(<0.001)$ & - \\
\hline Eriogonum microthecum & Burned $(0.097)$ & - \\
\hline Gayophytum diffusum & Burned (0.005) & - \\
\hline Gnaphalium palustre & Burned (0.099) & - \\
\hline Lappula occidentalis ssp. occidentalis & Unburned $(0.013)$ & - \\
\hline Lupinus caudatus ssp. caudatus & Burned $(0.001)$ & - \\
\hline Poa secunda & Unburned $(0.041)$ & - \\
\hline Microsteris gracilis ssp. gracilis & - & Interspace (0.004) \\
\hline Unknown herb 3 & Burned (0.046) & - \\
\hline Unknown herb 5 & Burned $(0.005)$ & - \\
\hline Unknown monocot 1 & - & Interspace $(0.065)$ \\
\hline
\end{tabular}

\section{Immediate Effects of Prescribed Burn on Germinable Seed Banks}

The most striking effect of the prescribed burn on the germinable seed bank was the decrease in seed density and species richness in the shrub litter layer. Temperature at the soil surface under shrubs reached $369^{\circ} \mathrm{C}$, and litter under shrubs and seeds in the litter were largely consumed by the fire. The majority of seeds lost were A. tridentata, a response noted in other shrubsteppe seed bank studies (Hassan and West 1986, Wehking 2002).

The apparent increase in seed density in the tree $0.01-0.05-\mathrm{m}$ soil layer was unexpected. Over $70 \%$ of the increase came from the winter annual D. pinnata. Because the fire did not increase soil temperature at this depth, heat shock does not explain the increased germination. Chemical cues from increased nitrogen availability or from smoke could also stimulate germination (Keeley et al. 1985, Karssen and Hilhorst 1992, Thanos and Rundel 1995, Baskin and Baskin 1998, Pérez-Fernández and Rodríguez-Echeverría 2003, Flematti et al. 2004). Whatever the cause for the increase, it is likely to be microsite-specific because the shrub 0.01$0.05-\mathrm{m}$ layer did not respond the same way as the tree 0.01-0.05-m layer, even though both microsites experienced similar temperatures and soil nutrient changes during the fire.

We assume that because this study occurred in early May before most plants produce seeds, post-burn changes in seed bank responses were induced by the prescribed burn and not new seed production. Only 1 species was known to have dispersed seeds during the interim between preburn and post-burn samplings: a Populus tremuloides grove upwind in the study canyon was dispersing seeds in May. Thirty Populus tremuloides seedlings emerged in the post-burn seed bank, but none were present in the preburn seed bank. Thus, we inferred that these post-burn P. tremuloides seeds were recently dispersed seeds, and consequently these seedlings were excluded from the analysis.

\section{Germinable Seed Banks Two Growing} Seasons after Prescribed Burn

A direct comparison of seed bank responses between preburn and post-burn data and data taken 2 growing seasons later is not possible due to the difference in the time of year that samples were collected. The spring 2002 preburn and post-burn samples represent quiescent seeds that remained in the seed bank after any natural spring germination events, and after granivore and fungal attack since their incorporation into the seed bank. Fall 2003 samples represent seeds from that year's new reproduction plus seeds already in the seed bank. Therefore, the adjacent unburned plot serves as a surrogate for what the seed bank would have been like without a prescribed burn, and any difference between burned and unburned plots is assumed to be a prescribed burn effect. 
All microsites differed in their composition between burned and unburned plots. Post-fire conditions on the burned plot, such as increased nutrients, reduced competition, differential tolerance to fire, and higher availability of light, may have allowed for greater establishment of or higher seed production from Eriogonum elatum, E. microthecum, and Gayophytum diffusum, compared to the unburned plot. An increased establishment of $G$. diffusum is not surprising, because this annual forb is prominent in post-fire vegetation in $P$. monophylla-J. osteosperma woodlands (Barney and Frischknecht 1974, Everett and Ward 1984). The dramatic increase in density of E. elatum and $E$. microthecum seeds was probably a result of higher seed production of surviving adults, because it is unlikely that Eriogonum species in the Great Basin form persistent seed banks (Meyer and Paulsen 2000). At our study site, E. elatum resprouted shortly after the May 2002 prescribed burn and had greater biomass and cover the following summer (2003) on the burned site than on the unburned site (Dhaemers 2006).

Species that dominated the seed bank of unburned plots, A. tridentata, D. pinnata, and L. occidentalis ssp. occidentalis, all occurred in burned plots but in much lower seed density. Because A. tridentata shrubs were killed by fire and have short-lived seeds with limited dispersal capabilities (about 90\% of its seeds disperse within $9 \mathrm{~m}$ of the adult shrub; Frischknecht 1978), reduction of $A$. tridentata in the post-fire seed bank is not surprising. In contrast, low seed density of $D$. pinnata and $L$. occidentalis ssp. occidentalis on burned plots was unexpected because both annual forbs are typically abundant post-fire (Everett and Ward 1984, Wehking 2002). As discussed above, D. pinnata had a large increase in germinable seeds immediately after the fire, primarily in the tree 0.01-0.05-m soil layer, which suggests a potential for initial high establishment following the spring burn. However, rapid growth of herbaceous perennials following the burn (Dhaemers 2006) may have reduced establishment and reproduction of annuals in general. By the 2nd growing season after the burn (summer 2003), which was the summer before long-term seed bank data were taken, cover of the 2 annual species was similar on burned and adjacent unburned plots (Dhaemers 2006). Thus, the increase in seed density immediately after the fire for these annuals did not necessarily result in long-term increases in plant or seed density.

Individual species' affinities towards specific microsite or fire conditions (Table 5) likely are a combination of response to fire, dispersal capabilities, and germination requirements. For instance, flowering of Microsteris gracilis (Hook.) Greene ssp. gracilis, an annual forb, increases after a fire (Wrobleski and Kauffman 2003). The exact cause for the increase is unknown but probably is related to post-burn increases in nutrients, light, and water. The association of Collinsia parviflora with shrub microsites has been documented in undisturbed P. monophylla-J. osteosperma woodlands (Koniak and Everett 1982) and is likely a result of high plant recruitment under shrubs and limited dispersal. Interestingly, this tendency towards shrub microsites persists even in burned plots.

Seed bank dynamics of Bromus tectorum followed a pattern similar to that observed in other studies. Seed density is initially reduced by fire but then quickly rebounds and surpasses initial densities (Hassan and West 1986, Humphrey and Schupp 2001). Although initial seed density in May 2002 was 14 seeds $\cdot \mathrm{m}^{-2}$ for B. tectorum, its density dropped to 0.8 seeds $\cdot \mathrm{m}^{-2}$ immediately after the fire. Two growing seasons later, the autumn seed bank on burned and unburned plots was 29 and 8 seed $\cdot \mathrm{m}^{-2}$, respectively. Compared to other seed bank studies, these densities are low, but B. tectorum establishment and reproduction at high elevations such as at our study site are limited by cold temperature constraints on growth (Chambers et al. 2007).

Most natural fires in this region occur in late summer and fall when fuels have peaked and humidity is low (Miller and Rose 1999). Thus, the effects of prescribed fires on the seed bank in spring undoubtedly differ from the effects of natural fires. For example, the initial prefire seed bank should be less dense in spring than in fall, and overall fire temperature should be lower in spring than in fall, which reduces the extent of seed death due to lethal temperatures. Thus, caution should be used when extrapolating results of this study to prescribed burns or wildfires that occur in late summer or fall.

\section{Summary}

Our results indicate that seed banks of encroaching $P$. monophylla-J. osteosperma 
woodlands often are dominated by annual grasses and forbs and the shrub A. tridentata, as found in seed banks of other Great Basin ecosystems (Hassan and West 1986, Wehking 2002). Adult plants and seeds of A. tridentata were largely lost during the spring prescribed burn, which reduced potential post-fire recruitment of this important shrub. Seed densities of perennial herbaceous grasses and forbs were low in both burned and unburned sites-typically only a few seeds per $\mathrm{m}^{2}$. Low abundance of shrubs and perennial grasses in the seed bank appears to limit postdisturbance plant recruitment in the Great Basin (Koniak and Everett 1982, Koniak 1985), and this feature is likely common in many other grasslands and shrublands (e.g., Coffin and Lauenroth 1989, O'Connor and Pickett 1992). Thus, recruitment from the seed bank is unlikely to facilitate vegetation recovery to prefire levels in encroaching P. monophylla-J. osteosperma woodlands of the Great Basin, especially for perennial species. We recommend that sites selected for restoration using prescribed fire have a cover of perennial herbaceous species sufficient to enable recovery of the site, and that the fire prescription minimize heat damage to those species.

\section{ACKNOWLEDGMENTS}

We wish to thank the following individuals for helping with field work, critiquing the manuscript, and assisting with statistical questions: Dr. Kim Allcock, Dr. L. Ben Bruce, Jessica Dhaemers, Scot Ferguson, Dr. George Fernandez, Kurt Jahn, Jacob Landmesser, Joe Toth, Ben Rau, and Alicia Reiner. Research was supported by the Nevada Arid Rangelands Initiative and the Nevada Agricultural Experiment Station.

\section{Literature Cited}

BALDWIN, I.T., AND L. MoRSE. 1994. Up in smoke II. Germination of Nicotiana attenuata in response to smokederived cues and nutrients in burned and unburned soils. Journal of Chemical Ecology 20:2373-2391.

Barney, M.A., AND N.C. FrischKnecht. 1974. Vegetation changes following fire in the pinyon-juniper type of west-central Utah. Journal of Range Management 27:91-96.

BASKIn, C.C., AND J.M. BASKIn. 1998. Seeds: ecology, biogeography, and evolution of dormancy and germination. Academic Press, Inc., San Diego, CA.

Bigwood, D.W., AND D.W. Inouye. 1988. Spatial patternanalysis of seed banks: an improved method and optimized sampling. Ecology 69:497-507.
Biondini, M.E., C.D. Bonham, and E.F. Redente. 1985. Secondary successional patterns in a sagebrush (Artemisia tridentata) community as they relate to soil disturbance and soil biological activity. Vegetatio 60:25-36.

BLANK, R.R., AND J.A. Young. 1998. Heated substrate and smoke: influence on seed emergence and plant growth. Journal of Range Management 51:577-583.

Chambers, J.C. 2001. Pinus monophylla establishment in an expanding Pinus-Juniperus woodland: environmental conditions, facilitation and interacting factors. Journal of Vegetation Science 12:27-40.

Chambers, J.C., and J.A. MacMahon. 1994. A day in the life of a seed: movements and fates of seeds and their implications for natural and managed systems. Annual Review of Ecology and Systematics 25:263292.

Chambers, J.C., J.A. MacMahon, and J.W. Haefner. 1991. Seed entrapment in disturbed alpine ecosystems: effects of soil particle size and diaspore morphology. Ecology 72:1668-1677.

Chambers, J.C., B.A. Roundy, R.R. Blank, S.E. Meyer, and A. Whittaker. 2007. What makes Great Basin sagebrush ecosystems invasible by Bromus tectorum? Ecological Monographs 77:117-145.

Christensen, N.L., and C.H. Muller. 1975. Effects of fire factors controlling plant growth in Adenostoma chaparral. Ecological Monographs 45:29-55.

Coffin, D.P., and W.K. Lauenroth. 1989. Spatial and temporal variation in the seed bank of a semiarid grassland. American Journal of Botany 76:53-58.

Dhaemers, J. 2006. Vegetation recovery following spring prescribed fire in pinyon-juniper woodlands of central Nevada: effects of elevation and tree cover. Master's thesis, University of Nevada, Reno.

Everett, R.L., S.H. Sharrow, and R.O. Meeuwig. 1983. Pinyon-juniper woodland understory distribution patterns and species associations. Bulletin of the Torrey Botanical Club 110:454-463.

EverETT, R.L., AND K. WARD. 1984. Early plant succession on pinyon-juniper controlled burns. Northwest Science 58:57-68.

Flematti, G.R., E.L. Ghisalberti, K.W. Dixon, and R.D. Trengove. 2004. A compound from smoke that promotes seed germination. Science 305:977.

Freas, K.E., AND P.R. Kemp. 1983. Some relationships between environmental reliability and seed dormancy in desert annual plants. Journal of Ecology 71:211217.

Frischnecht, N.C. 1978. Effects of grazing, climate, fire, and other disturbances on long-term productivity of sagebrush-grass ranges. Pages 633-635 in D. Hyder, editor, Proceedings of the First International Rangeland Congress; 1978 August 14-18. Society for Range Management, Denver, CO.

Gross, K.L. 1990. A comparison of methods for estimating seed numbers in the soil. Journal of Ecology 78:10791093.

Guo, Q., P.W. Rundel, AND D.W. Goodall. 1998. Horizontal and vertical distributions of desert seed banks: patterns, causes, and implications. Journal of Arid Environments 38:465-478.

Halpern, C.B., S.A. Evans, and S. Nielson. 1999. Soil seed banks in young, closed-canopy forests of the Olympic Peninsula, Washington: potential contributions to understory reinitiation. Canadian Journal of Botany 77:922-935. 
Hassan, M.A., and N.E. West. 1986. Dynamics of soil seed pools in burned and unburned sagebrush semideserts. Ecology 67:269-272.

Humphrey, L.D., AND E.W. SChupp. 2001. Seed banks of Bromus tectorum-dominated communities in the Great Basin. Western North American Naturalist 61: $85-95$.

Johnson, E.A., AND G.I. Fryer. 1992. Physical characterization of seed microsites-movement on the ground. Journal of Ecology 80:823-836.

Karssen, C.M., and H.W.M. Hilhorst. 1992. Effect of chemical environment on seed germination. Pages 327-348 in M. Fenner, editor, Seeds: the ecology of regeneration in plant communities. CABI Publishing, New York.

Keeley, J.E., B.A. Morton, A. Pedrosa, and P. Trotter, 1985. Role of allelopathy, heat and charred wood in the germination of chaparral herbs and suffrutescents. Journal of Ecology 73:445-458.

KemP, P.R. 1989. Seed banks and vegetation processes in deserts. Pages 257-281 in M.A. Leck, V.T. Parker, and R.L. Simpson, editors, The ecology of soil seed banks. Academic Press, Inc., San Diego, CA

KonIAK, S. 1985. Succesion in pinyon-juniper woodlands following wildfire in the Great Basin. Great Basin Naturalist 45:556-566.

KoniaK, S., AND R.L. Everett. 1982. Seed reserves in soils of successional stages of pinyon woodlands. American Midland Naturalist 108:295-303.

Korfmacher, J.L., J.C. Chambers, R.J. Tausch, B.A. Roundy, S.E. Meyer, and S. Kitchen. 2002. Technical note: a technique for conducting small-plot burn treatments. Journal of Range Management 56:251254.

McCune, B., AND J.B. Grace. 2002. Analysis of ecological communities. MjM Software Design, Gleneden Beach, OR.

McPherson, J.K., AND C.H. Muller. 1969. Allelopathic effects of Adenostoma fasciculatum, "Chamise," in the California chaparral. Ecological Monographs 39: $177-198$.

Meyer, S.E., and A. Paulsen. 2000. Chilling requirements for seed germination of $10 \mathrm{Utah}$ species of perennial wild buckwheat. Native Plants Journal 1:18-24.

Miller, R.F., AND J.A. Rose. 1999. Fire history and western juniper encroachment in sagebrush steppe. Journal of Range Management 52:550-559.

Miller, R.F., and R.J. Tausch. 2001. The role of fire in juniper and pinyon woodlands: a descriptive analysis. Pages 15-30 in K.E.M. Galley and T.P. Wilson, editors, Proceedings of the Invasive Species Workshop: the role of fire in the control and spread of invasive species. Fire Conference 2000: The First National Congress on Fire Ecology, Prevention, and Management. Miscellaneous Publications No. 11, Tall Timbers Research Station, Tallahassee, FL.

MiLLER, R.F., AND P.E. WigAND. 1994. Holocene changes in semiarid pinyon-juniper woodlands: response to climate, fire and human activities in the U.S. Great Basin. BioScience 44:465-474.

MontBlanc, E.M., J.C. Chambers, and P.F. Brussard. 2007. Variation in ant populations with elevation, tree cover, and fire in a pinyon-juniper-dominated watershed. Western North American Naturalist 67:469-491.

Naillon, D., K. Memmott, and S.B. Monsen. 1999. A comparison of understory species at three densities in a pinyon-juniper woodland. Pages $72-75$ in S.B.
Monsen and R. Stevens, compilers, Proceedings: ecology and management of pinyon-juniper communities within the interior West; 15-18 September 1997. RMRS-P-9. U.S. Department of Agriculture, Forest Service, Rocky Mountain Research Station, Ogden, UT.

O’Connor, T.G., And G.A. PicketT. 1992. The influence of grazing on seed production and seed banks of some African savanna grasslands. Journal of Applied Ecology $29: 247-260$

PÉrez-Fernández, M.A., AND S. Rodríguez-Echeverría. 2003. Effect of smoke, charred wood, and nitrogenous compounds on seed germination of ten species from woodland in central-western Spain. Journal of Chemical Ecology 29:237-251.

Rau, B.M., R.R. Blank, J.C. Chambers, and D.W. JohnSON. 2007. Prescribed fire in a Great Basin sagebrush ecosystem: dynamics of soil extractable nitrogen and phosphorus. Journal of Arid Environments $71: 362-375$.

Rau, B.M., J.C. Chambers, R.R. Blank, and W.W. Miller. 2006. Hydrologic response to prescribed fire in central Nevada pinyon-juniper (Pinus monophylla-Juniperus osteosperma) woodland. Journal of Range Management 58:614-622.

Reiner, A. 2004. Fuel load and understory community changes associated with varying elevation and pinyonjuniper dominance. Master's thesis, University of Nevada, Reno.

Steuter, A.A., And G.R. McPherson. 1995. Fire as a physical stress. Pages 550-579 in Wildland plants: physiological ecology and developmental morphology. Society for Range Management, Denver, CO.

Strickler, G.S., and P.J. Edgerton. 1976. Emergent seedlings from coniferous litter and soil in eastern Oregon. Ecology 57:801-807.

TAUSCH, R.J. 1999. Historic pinyon and juniper woodland development. Pages 12-19 in S.B. Monsen and R. Stevens, compilers, Proceedings: ecology and management of pinyon-juniper communities within the Interior West; 15-18 September 1997. RMRS-P-9. U.S. Department of Agriculture, Forest Service, Rocky Mountain Research Station, Ogden, UT.

Ter Heerdt, G.N.J., G.L. VerweiJ, R.M. Bekker, and J.P. BAKKER. 1996. An improved method for seed bank analysis: seedling emergence after removing the soil by sieving. Functional Ecology 10:144-151.

Thanos, C.A., AND P.W. Rundel. 1995. Fire-followers in chaparral: nitrogenous compounds trigger seed germination. Journal of Ecology 83:207-216.

Wenking, P.M. 2002. The role of the seed bank in the restoration of a big sagebrush dominated riparian corridor to a dry meadow. Master's thesis, University of Nevada, Reno.

Western Regional Climate Center. 2005. Austin, Nevada (260507), monthly climate summary, period of record: 1/1/1890 to 12/31/2005 [cited 13 April 2005]. Available from: http://www.wrcc.dri.edu/summary/climsmnv.html

Wrobleski, D.W., and J.B. KauffMan. 2003. Initial effects of prescribed fire on morphology, abundance, and phenology of forbs in big sagebrush communities in southeastern Oregon. Restoration Ecology 11:82-90.

Received 4 September 2007 Accepted 30 November 2007 